\begin{tabular}{c|c|c}
\hline \hline Vol. 232: 129-140, 2002 & $\begin{array}{c}\text { MARINE ECOLOGY PROGRESS SERIES } \\
\text { Mar Ecol Prog Ser }\end{array}$ & Published May 3 \\
\hline \hline
\end{tabular}

\title{
Organic carbon flux in Shiraho coral reef (Ishigaki Island, Japan)
}

\author{
Hiroshi Hata ${ }^{1,2, *}$, Setsuko Kudo ${ }^{2}$, Hiroya Yamano ${ }^{2,3}$, Norihide Kurano ${ }^{1}$, \\ Hajime Kayanne ${ }^{2,4}$ \\ ${ }^{1}$ Marine Biotechnology Institute, Kamaishi Laboratories, 3-75-1 Heita, Kamaishi City, Iwate 026-0001, Japan \\ ${ }^{2}$ Japan Science and Technology Corporation, 4-1-8 Honcho, Kawaguchi City, Saitama 332-0012, Japan \\ ${ }^{3}$ National Institute for Environmental Studies, 16-2 Onogawa, Tsukuba City, Ibaraki 305-8506 Japan \\ ${ }^{4}$ Department of Earth and Planetary Science, The University of Tokyo, 3-8-1 Hongo, Tokyo 113-0033, Japan
}

\begin{abstract}
Organic carbon flux and community production rates were estimated on Shiraho coral reef (Ishigaki Island, Japan) from 19 to 26 September 1998. The daily net community production $\left(P_{\mathrm{n}}\right)$ and respiration rate $(R)$ during the study period were 3 to 79 and $596 \mathrm{mmolC} \mathrm{m}{ }^{-2} \mathrm{~d}^{-1}$, respectively. This resulted in a daily gross community production $\left(P_{\mathrm{g}}\right)$ of 599 to $675 \mathrm{mmol} \mathrm{C} \mathrm{m}^{-2} \mathrm{~d}^{-1}$. The variation of $P_{\mathrm{n}}$ associated with the uncertainty of the curve fitting parameters of light response curves for photosynthesis was estimated using an error propagation formula. The averaged $P_{\mathrm{n}} \pm \mathrm{SE}$ was $36 \pm 12$ mmol C m${ }^{-2} \mathrm{~d}^{-1}(\mathrm{n}=23)$, indicating that the $P_{\mathrm{n}}$ was significantly positive $(t$-test, $\mathrm{p}<0.05)$. The apparent fluxes of dissolved organic carbon (DOC) and particulate organic carbon (POC) on the reef were estimated as 30 to 36 and 5 to $7 \mathrm{mmol} \mathrm{C} \mathrm{m}{ }^{-2} \mathrm{~d}^{-1}$, respectively; The sum of which was comparable with the $P_{\mathrm{n}}$ during the study period. The sediment trap study conducted at $1 \mathrm{~km}$ off the reef and $40 \mathrm{~m}$ depth showed that the vertical flux of POC was $1.0 \mathrm{mmol} \mathrm{C} \mathrm{m}{ }^{-2} \mathrm{~d}^{-1}$. The results indicated that 6 to $7 \%$ of the $P_{\mathrm{g}}$ was exported to offshore and about 14 to $20 \%$ of the POC exported from the reef flat and $0.2 \%$ of the $P_{\mathrm{g}}$ reached $1 \mathrm{~km}$ off and $40 \mathrm{~m}$ depth.
\end{abstract}

KEY WORDS: Coral reef $\cdot$ Shiraho $\cdot$ Community production $\cdot$ Carbon flux $\cdot$ DOC $\cdot$ POC $\cdot$ Sediment trap

\section{INTRODUCTION}

Coral reef flats and some reef communities maintain at least a 100- to 1000-fold greater biomass and a 10fold greater areal productivity than planktonic communities of tropical oligotrophic regions that are often called the 'deserts' of the sea (Lewis 1977). The high productivity of coral reef ecosystems in a low nutrient environment has been explained by tight recycling of inorganic nutrients within the reef ecosystem (Pomeroy 1970, Johannes \& Project Symbios Team 1972, Muscatine \& Porter 1977). Because of a 'tight recycling system', the net organic carbon production in the system has been regarded as close to zero. Many studies, however, have estimated that such a coral reef com-

\footnotetext{
*Present address: Hazama Technical Research Institute, 515-1, Karima, Tsukuba, Ibaraki 305-0822, Japan

E-mail: hata@eps.s.u-tokyo.ac.jp
}

munity has excess production (e.g. Smith 1973, Atkinson \& Grigg 1984, Barnes \& Lazar 1994, Kayanne et al. 1995, Gattuso et al. 1996). The results indicate the importance of more precise estimation of the net organic carbon production, as well as the information on the variability of daily metabolic parameters (Gattuso et al. 1996).

Direct measurements of the fluxes of organic materials in coral reef ecosystems are also needed to confirm the estimated positive net community production. The export of organic material from some reefs to the surrounding ocean has been suggested (Quasim \& Sankaranarayanan 1974, Taguchi 1982, Atkinson \& Grigg 1984). However, only a few reports have shown the direct measurements of the export of organic materials in coral reef environments (Delesalle et al. 1998, Hata et al. 1998). Studies on carbon fluxes not only within coral reef areas but also between the coral reef and surrounding ocean are necessary for understand- 
ing the carbon cycle in the entire coral reef; However, so far knowledge on coral-reef ecosystems is quite limited (Erez 1990).

In this study, we estimated community production and fluxes of organic materials in a coral reef (Shiraho reef, Isigaki Island, southwest Japan) and surrounding ocean, which in earlier studies had not been carried out simultaneously. The productivity was estimated using measurements of total alkalinity (TA) and total inorganic carbon (TIC), a combination of which should give the best accuracy and precision on carbon-based estimations. A new technique to evaluate the variation of daily metabolic estimations associated with the uncertainty of the curve fitting parameters of light productivity plots is proposed. A sediment trap study was made to evaluate the vertical flux of organic materials outside the reef, as well as the direct measurement of dissolved organic carbon (DOC) and particulate organic carbon (POC) fluxes in the reef site. Using the obtained data, the daily organic carbon budget in Shiraho reef during the study period was examined.

\section{MATERIALS AND METHODS}

Study site. The studies were conducted from 19 to 26 September 1998 on Shiraho reef $\left(24^{\circ} 25^{\prime} \mathrm{N}, 124^{\circ} 20^{\prime} \mathrm{E}\right)$, on the southeast coast of Ishigaki Island (Ryukyu Islands, southwest Japan; Fig. 1A). Ishigaki Island is in a monsoon area, where the prevailing wind directions are south in summer and north in winter. Shiraho reef is a fringing reef, which stretches about $1.3 \mathrm{~km}$ along the shore and is about $850 \mathrm{~m}$ wide (Fig. 1B). The geomorphology and water circulation defines the northern and southern boundary of the reef (Nakamori et al. 1991). The reef has a distinct topographical zonation from land to ocean: moat, reef pavement, reef crest and reef edge. (Iryu et al. 1995, Kayanne et al. 1995). The study site was at the middle of the reef pavement (Fig. 1B). Branched Porites and Montipora, and blue coral Heliopora were the dominant species of corals at the study site. A dense population of Heliopora coerulea in Shiraho reef is regarded as one of the world's oldest and largest colonies. Shiraho reef was bleached in the early summer 1998 (Kayanne et al. 1999a), and the study was made during the recovery from this bleaching. The area has a semi-diurnal tidal cycle, the ranges of which are about $150 \mathrm{~cm}$ at spring tide and about $50 \mathrm{~cm}$ at neap tide. The reef crest of Shiraho is frequently exposed at low tide periods. Water on the reef flat is isolated during the low tide (the 'slack-water period') for a maximum of $5.5 \mathrm{~h}$ and provides suitable conditions for metabolic measurements of the reef flat community (Kinsey 1975). The water on the reef flat is flushed out during high tide. The average residence time of water on the reef flat was estimated to be about 4 to $8 \mathrm{~h}$ (H. Yamano unpubl. data).

Monitoring the physical variables. Wind direction and velocity were monitored using a sensor (KDC-S4)
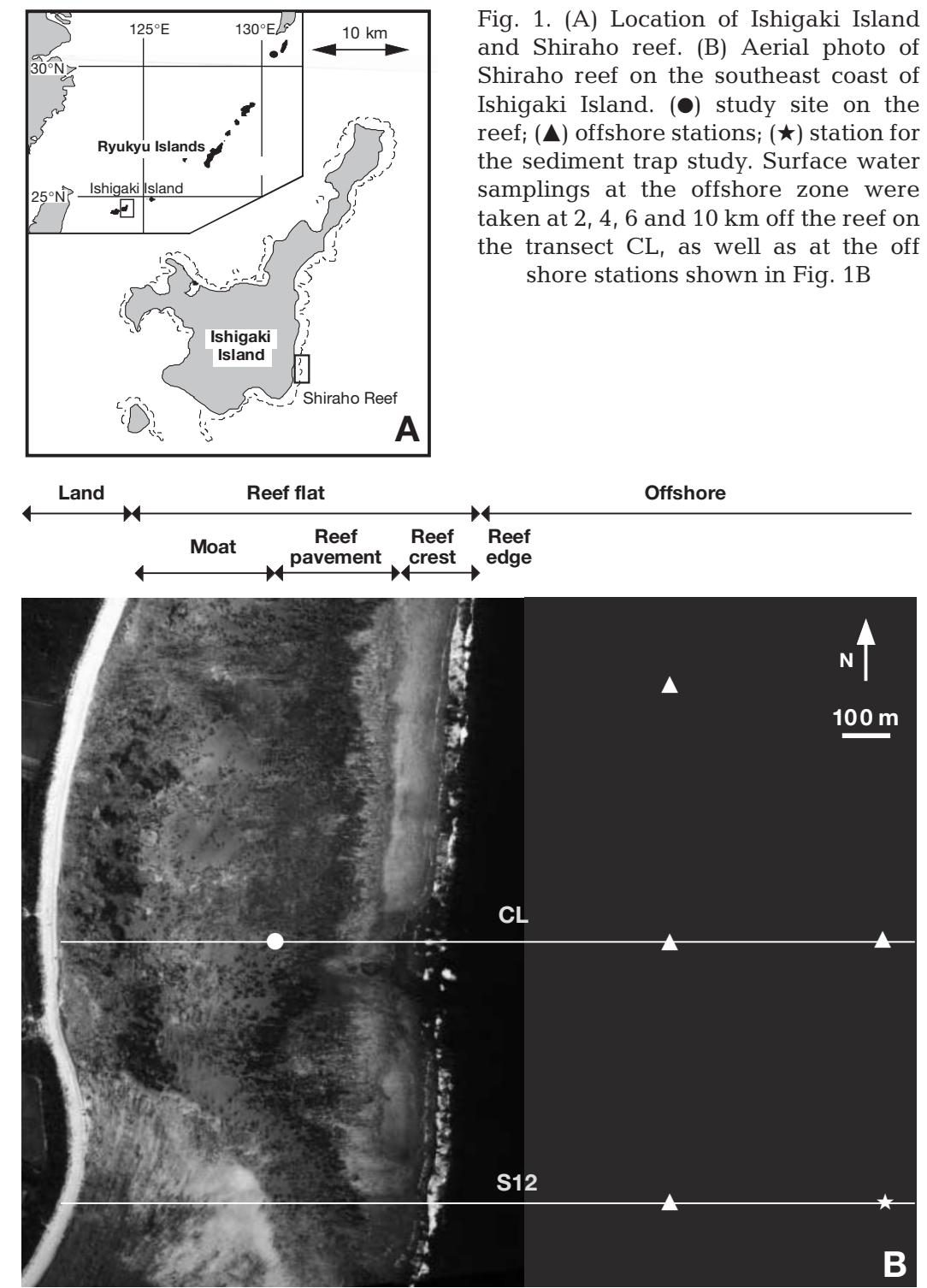

Fig. 1. (A) Location of Ishigaki Island and Shiraho reef. (B) Aerial photo of Shiraho reef on the southeast coast of Ishigaki Island. (๑) study site on the reef; $(\boldsymbol{\Delta})$ offshore stations; $(\star)$ station for the sediment trap study. Surface water samplings at the offshore zone were taken at 2, 4, 6 and $10 \mathrm{~km}$ off the reef on the transect $\mathrm{CL}$, as well as at the off shore stations shown in Fig. 1B 
connected to a recorder (KADEC-KAZE). Precipitation was monitored using a rain gauge (KDC-S13) connected to a recorder (KADEC-PLS; All equipment was from KONA System). The wind and precipitation were measured at the land station at about $8 \mathrm{~m}$ elevation $1.5 \mathrm{~km}$ southwest from the study point.

The water depth was measured every $15 \mathrm{~min}$ at the study point using a depth sensor (Argonaut-XR, SonTek). The beginning of the slack water period was identified by exposure of the reef crest. Most other parameters were measured using a newly developed integrated monitoring system equipped on research boat 'CREST' anchored at the study point (Kayanne et al. in press). Salinity and water temperature were monitored every minute using a water quality sensor sonde (H20 sensor, Hydrolab). The underwater irradiance was measured using a LI-192SA quantum sensor (Li-Cor) set on the sea floor, and was logged every minute to a personal computer on the boat.

Sampling procedures. Surface waters at the reef and offshore stations were sampled daily from 20 to 24 and 26 September 1998, respectively. For analyses of TA and TIC, $1 \mathrm{l}$ of seawater was put into a glass bottle and was stored in the dark at 4 to $10^{\circ} \mathrm{C}$ until analysis within $12 \mathrm{~h}$. A $250 \mathrm{ml}$ seawater sample was used to measure the salinity. To measure DOC, $30 \mathrm{ml}$ of seawater was filtered through a glass fiber filter (GF/F Whatman) (combusted beforehand at $550^{\circ} \mathrm{C}$ for $1 \mathrm{~h}$ ) and were stored in a glass bottle at $-20^{\circ} \mathrm{C}$ until analysis. To measure POC and particulate organic nitrogen (PON), 21 of seawater were collected in a polyethylene container and kept in a refrigerator pending filtration within $6 \mathrm{hr}$ in the field laboratory. The sample was filtered through a $25 \mathrm{~mm} \mathrm{GF} / \mathrm{F}$ and was stored at $-20^{\circ} \mathrm{C}$. To examine the particulate flux outside the reef, a time-series sediment trap (Model SMC7S-500, Nichiyu Giken Kogyo) was set $1 \mathrm{~km}$ from the reef and at $40 \mathrm{~m}$ depth $(20 \mathrm{~m}$ above the bottom) from 20 to 26 September 1998 (Fig. 1B). Seven sample bottles were filled with filtered seawater containing $25 \mathrm{~g} \mathrm{l}^{-1} \mathrm{NaCl}$ to increase the density and $2 \%$ neutralized formaldehyde, and were screwed into a rotary disc perpendicular to the funnel. When the disk rotated, 1 sample bottle moved forward and the next bottle replaced it at a set time previously programmed. Each bottle was set for $1 \mathrm{~d}$, the time of which was synchronized to the tide table. The collected bottles were sealed and stored at $4^{\circ} \mathrm{C}$ until analysis.

Analytical procedures. In the laboratory, the TA and TIC were measured using a precision analyzer (Model EN-501A, Kimoto Electric) in conjunction with instructions from a US Department of Energy handbook (DOE 1994, Kimoto et al. 2002). The TIC data in this study was measured using a coulometer (CM5012, UIC), which was connected to the analyzer. The precision for measuring TA and TIC was $2 \mu \mathrm{mol} \mathrm{kg}{ }^{-1}$ for both vari- ables. The salinity was measured using a salinometer (Portsal 8410A, Guildline Instruments). The DOC was measured by a high temperature catalytic oxygen method associated with a non-dispersive infrared analyzer (TOC-5000, Shimadzu). The data were calculated against standards prepared using glucose. Procedures to analyze suspended and trapped particles mostly followed Hata et al. (1998). The POC and PON in suspended and trapped particles were measured using a carbon-hydrogen-nitrogen (CHN) analyzer (MT-5, Yanaco) after $\mathrm{HCl}$ fume treatment to remove inorganic carbon (Yamamuro \& Kayanne 1995).

Data processing. The data for specific conductance obtained by the seawater sensor sonde were converted into salinity according to the definition of UNESCO (1981), the formula of which is also detailed in Müller (1999). The calculated data were compared with the data obtained using a salinometer. Systematic error was $0.02 \pm 0.01$ PSU during the study period, which was corrected accordingly. Both organic and inorganic carbon production rates of the reef community were calculated from the changes in TA and TIC during the slack-water period of reef water (Smith \& Key 1975).

Eqs. (1) and (2) demonstrate the calculations for the inorganic carbon production (net calcification, $g_{\mathrm{n}}$ ) rate and organic carbon production (net photosynthesis, $p_{\mathrm{n}}$ ) rate, respectively:

$$
\begin{gathered}
g_{\mathrm{n}}\left(\mathrm{mmolC} \mathrm{m}^{-2} \mathrm{~h}^{-1}\right)=-\frac{\mathrm{dTA}}{2} \times \rho \times D \times t^{-1} \times 10^{-3} \\
p_{\mathrm{n}}\left(\mathrm{mmolC} \mathrm{m}^{-2} \mathrm{~h}^{-1}\right)=-\left(\mathrm{dTIC}-\frac{\mathrm{dTA}}{2}\right) \times \rho \times D \times t^{-1} \times 10^{-3}
\end{gathered}
$$

where dTA is change in total alkalinity $\left(\mu \mathrm{mol} \mathrm{kg}^{-1}\right)$, dTIC is change in total inorganic carbon ( $\mu \mathrm{mol} \mathrm{kg}{ }^{-1}$ ), $\rho$ is seawater density $\left(\mathrm{kg} \mathrm{m}^{-3}\right)$ as, given by Millero \& Pisson (1981), $D$ is water depth (m) averaged for a $50 \times$ $50 \mathrm{~m}$ range around the study site based on relative height data of 25 grids. and $t$ is duration $\left(\mathrm{h}^{-1}\right)$.

The respiration rate $(r)$ was obtained by $p_{\mathrm{n}}$ measured at night. The gross community production rate $\left(p_{\mathrm{g}}\right)$ was given by the sum of $p_{\mathrm{n}}$ and $|r|$.

The rates of $p_{\mathrm{n}}$ and $g_{\mathrm{n}}$ were plotted against the light intensity. The hyperbolic tangent function (tanh) was used to obtain light-saturation curves of photosynthesis and calcification as recommended by Chalker (1981):

$$
p_{\mathrm{n}}=p_{\max } \times \tanh \left(i / I_{\mathrm{k}}\right)+r
$$

where $p_{\max }$ is the maximum photosynthesis rate, $I_{\mathrm{k}}$ is the constant determined by the initial slope and $p_{\max }$ (Chalker 1981), $r$ is the respiration rate (see above), and $i$ is light intensity, when the curve was fitted for the calcification, $p_{\mathrm{n}}=g_{\mathrm{n}}, p_{\max }=g_{\max }$ and $r=g_{\mathrm{n}}$ at night. The curve fitting was computed using SYSTAT 5 running on 
a Macintosh computer. Daily production rates were calculated by integrating the production rates with daily light intensity. Gattuso et al. (1996) pointed out that simulated light data (e.g. a sine curve) grossly overestimates the daily average daily irradiance. The data was processed using light data collected at the site for every min in order to avoid such an overestimation. The daily net community production $\left(P_{\mathrm{n})}\right.$, daily community respiration rate $(R)$, gross community production $\left(P_{\mathrm{g}}\right)$ and net community calcification $\left(G_{\mathrm{n}}\right)$ were obtained by integration for $p_{\mathrm{n}},|r|, p_{\mathrm{g}}$ and $g_{\mathrm{n}}$ for $24 \mathrm{~h}$, respectively.

Evaluation of the error of daily production estimates. To evaluate the variation of the daily metabolic estimations associated with the uncertainty of the curve fitting parameters, we used the general formula of error propagation (Taylor 1982). For convenience, the hyperbolic function (Eq. 3) is expressed in the following:

$$
\begin{aligned}
p & =f(x, y, z) \\
& =x \times \tanh (i / y)+z \\
& =x \times \frac{e^{2 i / y}-1}{e^{2 i / y}+1}+z
\end{aligned}
$$

The ' $i$ ' represents light intensity, which is treated as a constant in the equation. The standard deviation (SD) of ' $p$ ' $\left(\sigma_{p}\right)$ at a fixed light intensity (i) derived from the error of $x, y$ and $z$ can be calculated as follows:

$$
\begin{aligned}
\sigma_{p}^{2}= & \left(\frac{\partial p}{\partial x}\right)^{2} \sigma_{x}^{2}+\left(\frac{\partial p}{\partial y}\right)^{2} \sigma_{y}^{2}+\left(\frac{\partial p}{\partial z}\right)^{2} \sigma_{z}^{2} \\
& +2 \frac{\partial p}{\partial x} \frac{\partial p}{\partial y} \sigma_{x y}+2 \frac{\partial p}{\partial x} \frac{\partial p}{\partial z} \sigma_{x z}+2 \frac{\partial p}{\partial y} \frac{\partial p}{\partial z} \sigma_{y z}
\end{aligned}
$$

$\sigma_{x}^{2}, \sigma_{y}^{2}$ and $\sigma_{z}^{2}$ represent the variances of $x, y$ and $z$, respectively. The $\sigma_{x y}, \sigma_{y z}$ and $\sigma_{z x}$ represent covariances between $x, y$ and $z$. If the errors of $x, y$ and $z$ are random and independent of each other, then all covariances equal 0 ; However this is not the case in the hyperbolic tangent function. The $\partial p / \partial x, \partial p / \partial y$ and $\partial p / \partial z$ represent the partial derivatives for $x, y$ and $z$, respectively, as follows:

$$
\begin{aligned}
& \frac{\partial p}{\partial x}=\tanh (i / y) \\
& \frac{\partial p}{\partial y}=-\frac{4 i e^{2 i / y}}{y^{2} \times\left(e^{2 i / y}+1\right)} \times x \\
& \frac{\partial p}{\partial z}=1
\end{aligned}
$$

To obtain the SD of the $P_{\mathrm{n}}$, which is integrated against irradiance data, Eq. (5) should be converted as follows:

$$
\begin{aligned}
\sigma_{P_{\mathrm{n}}}^{2}= & \left(\sum \frac{\partial p}{\partial x} \Delta t\right)^{2} \sigma_{x}^{2}+\left(\sum \frac{\partial p}{\partial y} \Delta t\right)^{2} \sigma_{y}^{2}+\left(\sum \frac{\partial p}{\partial z} \Delta t\right)^{2} \sigma_{z}^{2} \\
& +2\left(\sum \frac{\partial p}{\partial x} \Delta t\right)\left(\sum \frac{\partial p}{\partial y} \Delta t\right) \sigma_{x y}+2\left(\sum \frac{\partial p}{\partial x} \Delta t\right) \\
& \times\left(\sum \frac{\partial p}{\partial z} \Delta t\right) \sigma_{x z}+2\left(\sum \frac{\partial p}{\partial y} \Delta t\right)\left(\sum \frac{\partial p}{\partial z} \Delta t\right) \sigma_{y z}
\end{aligned}
$$

where $\Delta t$ is the interval for integrated data (1 $\mathrm{min})$.

The SD of the mean (SDOM: $\sigma_{\bar{P}_{\mathrm{n}}}$ ), which is often expressed as standard error (SE), is given by:

$$
\sigma_{\bar{P}_{\mathrm{n}}}=\sigma_{P_{\mathrm{n}}} / \sqrt{\mathrm{N}}
$$

$\mathrm{N}$ is the number of the data.

The variances and covariances of the curve fitting parameters were calculated using an N-88 BASIC program for least-square method (KOTARO, Sankaido) programmed after Sato (1997).

\section{RESULTS AND DISCUSSION}

\section{Environmental conditions}

The underwater light intensity was $1500 \mu \mathrm{mol} \mathrm{m} \mathrm{m}^{-2} \mathrm{~s}^{-1}$ at $12: 00$ h (Fig. 2a), which was about 50 to $60 \%$ of that in air found during the study period. The water depth measurements indicated that the slack water period started at a depth below $155 \mathrm{~cm}$ and ended with a rise of water level (Fig. 2c). The water temperature was 28 to $30^{\circ} \mathrm{C}$, and the maximum and minimum temperatures were at the end of the slackwater period during the day and night, respectively. Reef water salinity was 34.4 to 34.8 PSU, which increased during the day slack water period because of evaporation and decreased after precipitation (Fig. 2b,e). A salinity decrease caused by inflow of river water and underground water did not occur at the study point during the study period. The concentrations of inorganic nitrogen $\left(\mathrm{NO}_{3}{ }^{-}+\mathrm{NO}_{2}{ }^{-}+\right.$ $\left.\mathrm{NH}_{4}{ }^{+}\right)$and phosphorus $\left(\mathrm{PO}_{4}{ }^{3-}\right)$ during the study periods were about 1 to 2 and 0.01 to $0.04 \mu \mathrm{M}$, respectively (T. Miyajima unpubl. data).

\section{Daily production rates}

The TA and TIC in the reef water were 2150-2295 and 1570-2085 $\mu \mathrm{mol} \mathrm{kg} \mathrm{kg}^{-1}$, respectively, and in the offshore water were 2263-2270 and 1915-1922 $\mu \mathrm{mol} \mathrm{kg}{ }^{-1}$, respectively. The TA and TIC decreased during the day and increased during the night. This was due to photosynthesis (TIC decrease) and calcification (TIC and TA decrease) during the day and respiration (TIC increase) during the night. The rates of calcification and photosynthesis calculated by Eqs. (1) and (2) were 
plotted against light intensity (Fig. 3). Curve fitting parameters for calcification and photosynthesis simulated by the hyperbolic tangent function (Eq. 3) were obtained by the resulting curves. Daily production rates were calculated by integrating the production curves with daily light intensity (Table 1). The $P_{\mathrm{n}}$ was 3 to 79 , at an average of $36 \mathrm{mmolC} \mathrm{m} \mathrm{m}^{-2} \mathrm{~d}^{-1}$. $R$ was
$596 \mathrm{mmolC} \mathrm{m} \mathrm{m}^{-2} \mathrm{~d}^{-1}$. Thus resulted in $P_{\mathrm{g}}$ of 599 to 675

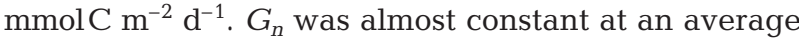
of $127 \mathrm{mmolC} \mathrm{m} \mathrm{m}^{-2} \mathrm{~d}^{-1}$. The data were revised from the report by Kayanne et al. (1999b), by reconsidering the water depth data (see 'Materials and methods'). Several studies have been made of the community metabolism of Shiraho reef. (Nakamori et al. 1991, Suzuki et

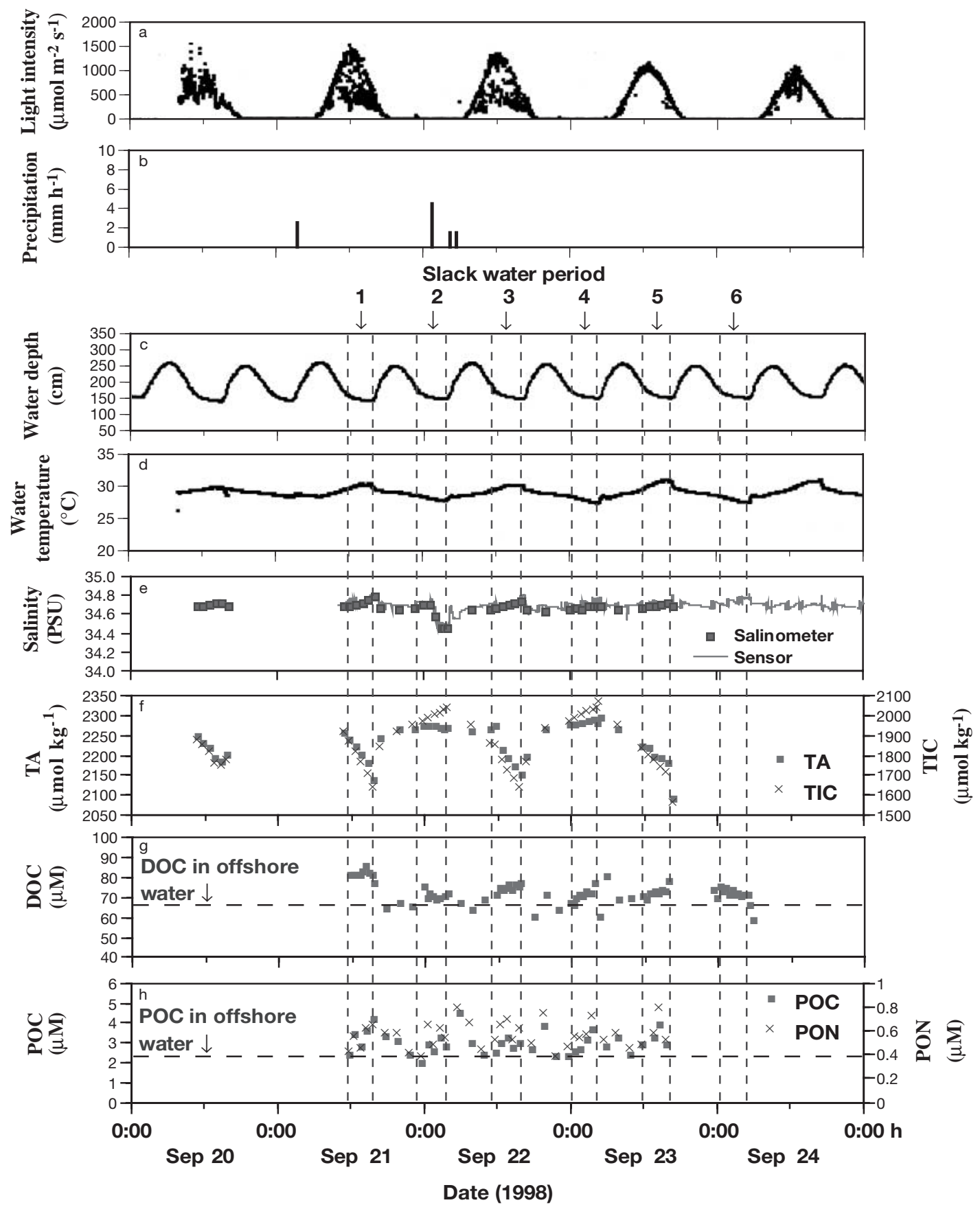

Fig. 2. Time series of physical and chemical parameters in seawater on the Shiraho reef flat from 20 to 24, September 1998. TA: total alkalinity; TIC: total inorganic carbon; DOC: dissolved organic carbon; POC: particulate organic carbon; and PON: particulate organic nitrogen 
Table 1. Daily community production rates of Shiraho reef during the study period (21 to 24 September 98). $I$ is daily integrated irradiance, $P_{\mathrm{g}}$ is daily gross community production, $R$ is daily community respiration rate, $P_{\mathrm{n}}$ is daily net community production and $G_{n}$ is net daily community calcification

\begin{tabular}{|c|c|c|c|c|c|}
\hline $\begin{array}{l}\text { Date } \\
(1998)\end{array}$ & $\begin{array}{c}I \\
\left.\mathrm{~mol} \mathrm{\textrm {m } ^ { - 2 }} \mathrm{d}^{-1}\right)\end{array}$ & $P_{g}$ & $\begin{array}{c}R \\
(\mathrm{mmol}\end{array}$ & $\begin{array}{c}P_{\mathrm{n}} \\
\left.\mathrm{m}^{-2} \mathrm{~d}^{-1}\right)\end{array}$ & $G_{n}$ \\
\hline $21 \mathrm{Sep}$ & 22 & 622 & -596 & 26 & 128 \\
\hline 22 Sep & 21 & 599 & -596 & 3 & 127 \\
\hline $23 \mathrm{Sep}$ & 24 & 675 & -596 & 79 & 126 \\
\hline 24 Sep & 20 & 631 & -596 & 36 & 128 \\
\hline Daily average & 22 & 632 & -596 & $36 \pm 12^{\mathrm{a}}$ & 127 \\
\hline \multicolumn{6}{|c|}{$\begin{array}{l}\text { aEstimated SE associated with the uncertainty of the } \\
\text { curve fitting parameters (see text) }\end{array}$} \\
\hline
\end{tabular}

al. 1995). The $P_{\mathrm{g}}$ of coral communities on Shiraho reef in September 1990 was 412 to $460 \mathrm{mmolC} \mathrm{m}^{-2} \mathrm{~d}^{-1}$. The community metabolism at the same point as this study was $434 \mathrm{mmolC} \mathrm{m}^{-2} \mathrm{~d}^{-1}$ in March 1993 (Kayanne et al. 1995). The range of the reported data is attributable to spatial and seasonal variation; However, the $P_{\mathrm{n}}$ of the study period (36 mmolC m $\mathrm{m}^{-2} \mathrm{~d}^{-1}$ ) was at a lower limit than found in previous studies (26 to $110 \mathrm{mmolC} \mathrm{m}^{-2}$ $\mathrm{d}^{-1}$ ). The lower $P_{\mathrm{n}}$ can be explained by the lower coverage of corals because of a bleaching event $(\mathrm{H}$. Kayanne et al. unpubl. data). During the study period (September 98), the coverage of corals was $7.1 \%$ with $50 \%$ bleaching. Therefore, the coverage of healthy corals was $3.6 \%$ (half of $7.1 \%$ ). The bleached corals were also still alive and they played a role as consumers in the ecosystem and this in turn lowered $P_{\mathrm{n}}$

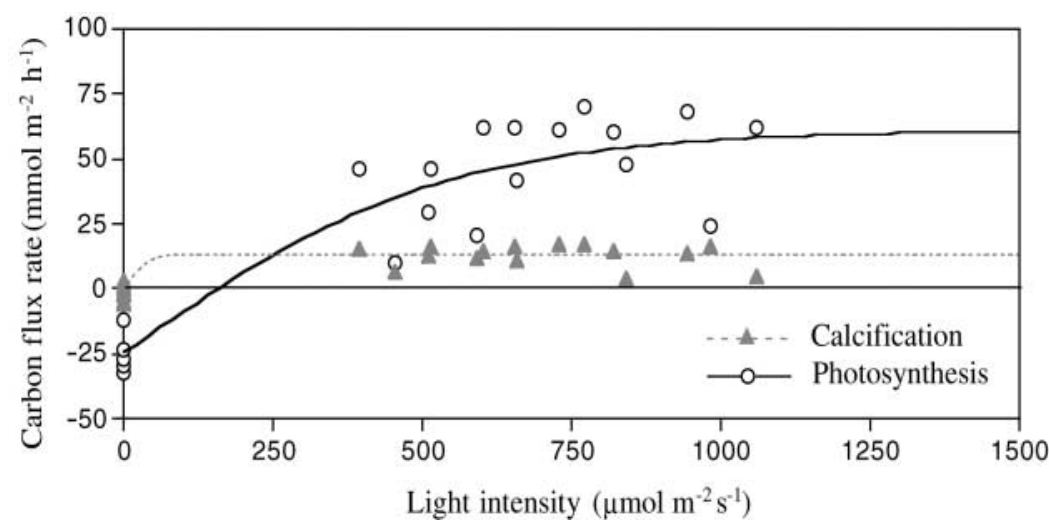

Fig. 3. Light response curves for photosynthesis and calcification. The fitting equation is hyperbolic tangent function (see text). The curve fitting parameters (mean $\pm \mathrm{SE}$ ) for photosynthesis and calcification are: Photosynthesis $\left(\mathrm{mmol} \mathrm{m}^{-2} \mathrm{~h}^{-1}\right): p_{\max }=86 \pm 2, I_{\mathrm{k}}=526 \pm 36, r=25 \pm 1\left(\mathrm{r}^{2}=0.872\right)$. Calcification $\left(\mathrm{mmol} \mathrm{m}^{-2} \mathrm{~h}^{-1}\right): g_{\max }=15 \pm 0.4, I_{\mathrm{k}}=35 \pm 44, g_{\mathrm{n}}$ at night $=2 \pm 0.3$ $\left(\mathrm{r}^{2}=0.771\right)$. The curve fitting parameters were calculated by SYSTAT 5 running on a Macintosh computer. The N-88 BASIC program (KOTARO, Sankaido), that was programmed after Sato (1997), calculated the SEs of the curve fitting parameters during the study period. The productivity measured 1 yr later (September 99), when the coverage recovered to $6.7 \%$, showed that $P_{\mathrm{n}}$ was $113 \mathrm{mmolC} \mathrm{m} \mathrm{m}^{-2} \mathrm{~d}^{-1}$.

\section{Error analysis of daily production rate}

The ratio of gross photosynthesis to respiration $\left(P_{\mathrm{g}} / R\right)$ was $1.06 \pm 0.03(\mathrm{n}=4)$, indicating that the reef system was autotrophic. The SE of the $P_{\mathrm{n}}$ associated with the uncertainty of the curve fitting parameters (estimated by Eq. 7) was $12 \mathrm{mmolC} \mathrm{m} \mathrm{m}^{-2} \mathrm{~d}^{-1}$. The data (36 \pm $12 \mathrm{mmolC} \mathrm{m} \mathrm{m}^{-2}: \mathrm{n}=23$ ) indicated that the $P_{\mathrm{n}}$ was significantly positive $(t$-test, $\mathrm{p}<0.05)$ during the study period. Gattuso et al. (1996) pointed out the importance of evaluating the uncertainty of estimated daily metabolic parameters and proposed a Monte Carlo simulation method. The Monte Carlo method, however, is a numeric experimental which provides a solution as a rough approximation (Miyatake \& Wakimoto 1978). In this report, we introduced the theoretical and statistical method. We computed a propagated error derived from the asymptotic SEs of curve fitting parameters (Eq. 5). An integrated form of propagation of error (Eq. 7) was a new formula to obtain the confidence interval in the daily metabolic parameters, which provided the best estimator.

\section{Concentrations and fluxes of DOC and POC on the reef}

This report is the first to study the concentrations and fluxes of DOC and POC in seawater on Shiraho reef. The concentrations of DOC (60 to $87 \mu \mathrm{M}$, average 72 ), POC (2.0 to $4.5 \mu \mathrm{M}$, average 3.1 ) and PON (0.39 to $0.81 \mu \mathrm{M}$, average 0.57) were lower compared with the data reported for other reef sites, reviewed by Sorokin (1993) and Torreton et al. (1997); this is mainly attributable to the shorter residence time (4 to $8 \mathrm{~h}$ ) of the water in the study area. The lower $P_{\mathrm{n}}$ during the study period discussed above might relate to lower concentrations of DOC and POC, but it remains to be studied. The concentrations of DOC, POC and PON in offshore water (average $\pm \mathrm{SE}$ ) were $68 \pm 3(\mathrm{n}=$ 5), $2.3 \pm 0.2(\mathrm{n}=10)$ and $0.45 \pm 0.02(\mathrm{n}=10)$ $\mu \mathrm{M}$, respectively. The concentrations of DOC, POC and PON were higher in reef water during the slack water period than those in offshore water both during the day and night, and were returned to the offshore value during the high tide period (Fig. 2). Such diurnal patterns suggested an input of organic materials into ambient water on the reef flat and the net export of organic mate- 
rials from the reef to offshore. The results were consistent with the positive $P_{\mathrm{n}}$.

Two types of estimation for the fluxes of DOC and POC were made. First, the rates of the changes in DOC and POC during slack water periods were calculated by a regression analysis (Table 2, Fig. 4). The slope of the regression ( $\mu \mathrm{mol} \mathrm{l}^{-1} \mathrm{~h}^{-1}$ ) was considered a net flux during the periods. To estimate the daily fluxes of DOC

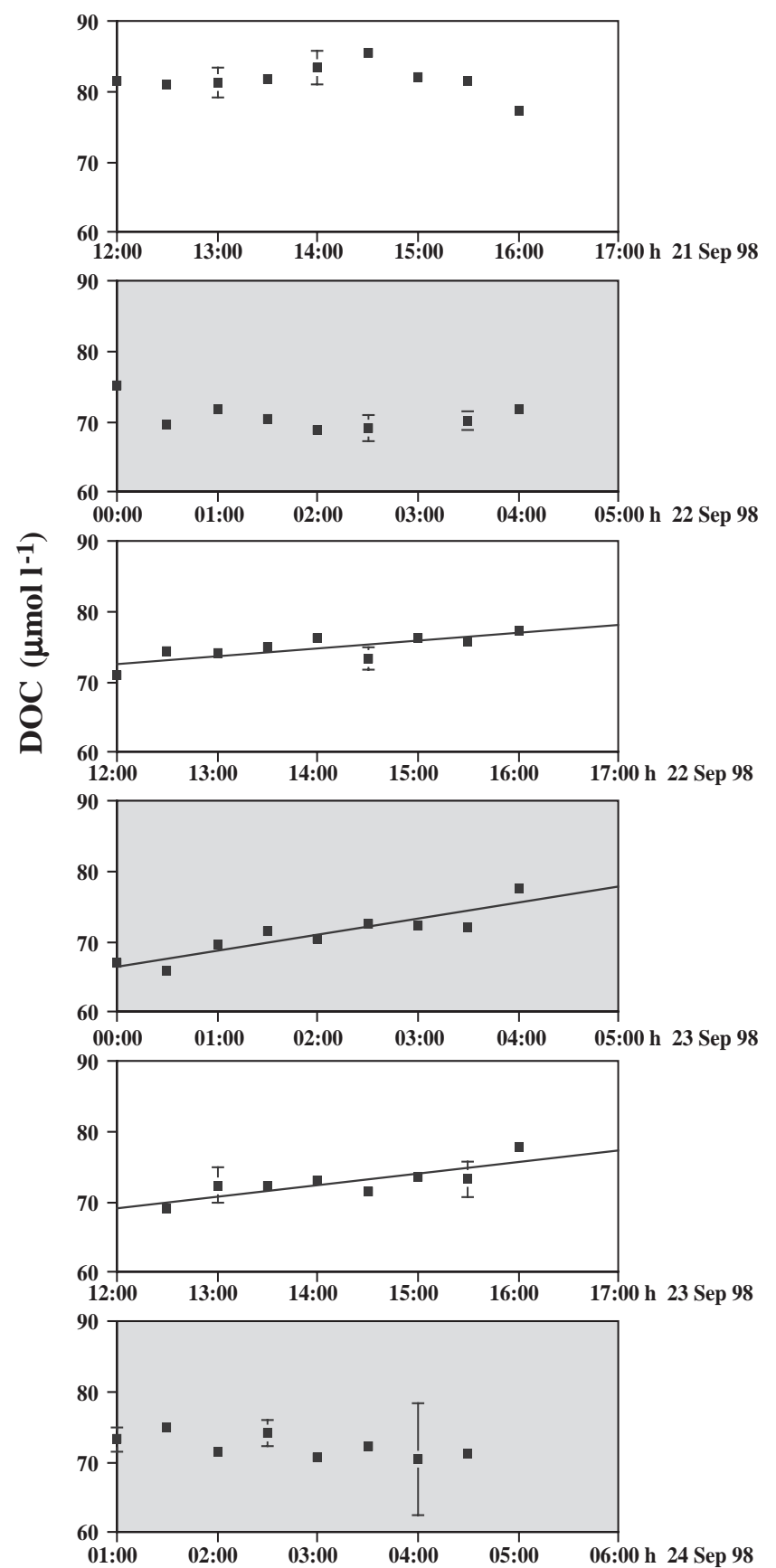

and POC on the reef, the calculated fluxes of DOC and POC during the slack water period was integrated for each $12 \mathrm{~h}$ period of the day and night. The averaged DOC and POC fluxes were 30 and $5 \mathrm{mmolC} \mathrm{m} \mathrm{m}^{-1}$, respectively. The changes in the concentrations of DOC were sometimes negative, though they were not significant (Table 2). We suppose that the apparent negative flux of DOC occurred by the occasional larger
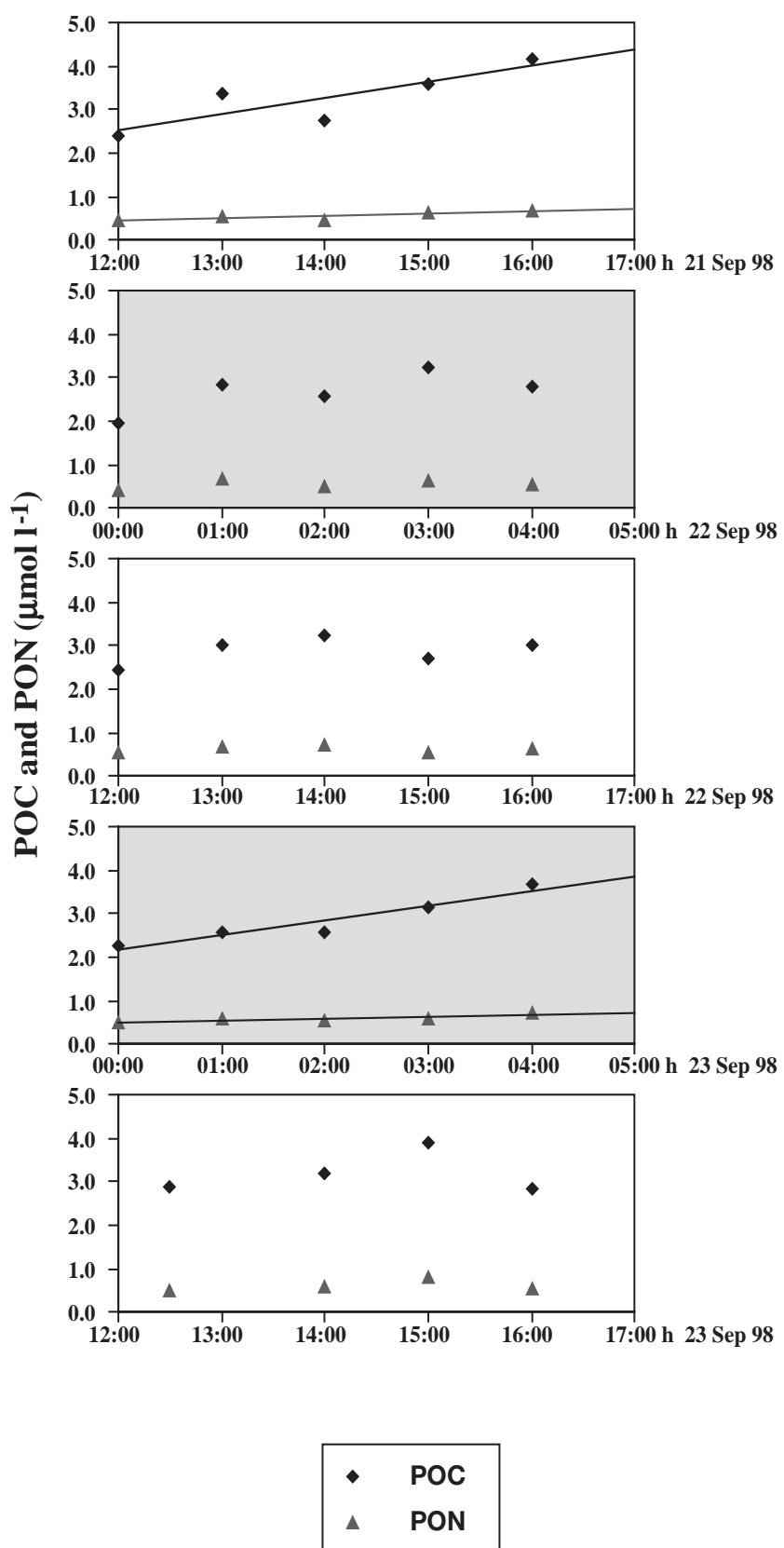

Fig. 4. Changes in the concentrations of DOC, POC and PON during slack-water periods on the Shiraho reef flat (21 to 24 September 1998). The shaded frames are data at night (00:00 to 05:00 h, except 24 September with data from 01:00 to 06:00 h), unshaded frames are data in the day (12:00 to 17:00h) 
Table 2. Estimations of organic carbon flux in Shiraho reef (21 to 24 September 1998). ns: not significant, the net flux being regarded as $0 ; \mathrm{nm}$ : not measured. Averaged water depth of $151 \mathrm{~cm}$ during the slack water period was used in the calculation of integrated flux. ${ }^{*} \mathrm{p}<0.1,{ }^{* *} \mathrm{p}<0.05,{ }^{* * *} \mathrm{p}<0.01$

\begin{tabular}{|c|c|c|c|c|c|c|}
\hline \multirow[b]{2}{*}{ Date (1998) } & \multirow[b]{2}{*}{$\begin{array}{l}\text { Number } \\
\text { of the data }\end{array}$} & \multirow{2}{*}{$\begin{array}{c}\text { Rate } \pm \text { SE } \\
\left(\mu \mathrm{mol} \mathrm{l} l^{-1} \mathrm{~h}^{-1}\right)\end{array}$} & \multirow[b]{2}{*}{$\begin{array}{l}\text { Integrated flux for } 12 \mathrm{~h} \\
\quad\left(\mathrm{mmol} \mathrm{m}^{-2}\right)\end{array}$} & \multirow{2}{*}{$\begin{array}{l}\text { Number } \\
\text { of the data }\end{array}$} & \multicolumn{2}{|c|}{ POC } \\
\hline & & & & & $\begin{array}{c}\text { Rate } \pm \text { SE I } \\
\left(\mu \mathrm{mol} l^{-1} \mathrm{hr}^{-1}\right)\end{array}$ & $\begin{array}{l}\text { Integrated flux for } 12 \mathrm{~h} \\
\qquad\left(\mathrm{mmol} \mathrm{m}^{-2}\right)\end{array}$ \\
\hline 21 Sep (day) & 9 & $-0.4 \pm 0.8$ & ns & 5 & $0.37 \pm 0.13^{*}$ & 6.6 \\
\hline 22 Sep (night) & 8 & $-0.6 \pm 0.6$ & ns & 5 & $0.21 \pm 0.13$ & ns \\
\hline 22 Sep (day) & 9 & $1.1 \pm 0.3^{* *}$ & 20 & 5 & $0.09 \pm 0.10$ & ns \\
\hline 23 Sep (night) & 9 & $2.2 \pm 0.4^{* * *}$ & 41 & 5 & $0.33 \pm 0.06^{* * *}$ & 6.1 \\
\hline 23 Sep (day) & 8 & $1.6 \pm 0.5^{* * *}$ & 29 & 4 & $0.07 \pm 0.19$ & ns \\
\hline 24 Sep (night) & 8 & $-0.9 \pm 0.4$ & ns & $\mathrm{nm}$ & & \\
\hline Total & & & 90 & & & 12.7 \\
\hline Daily average & & & 30 & & & 5.1 \\
\hline
\end{tabular}

heterotrophic consumption of DOC than excretion of DOC by primary producers (discussed in the following section). Second, the fluxes of DOC and POC were calculated by the difference in the concentrations of DOC and $\mathrm{POC}$ in reef water and offshore water and the residence time of reefwater:

Flux $\left(\mathrm{mmol} \mathrm{m}^{-2} \mathrm{~d}^{-1}\right)=$

$([\mathrm{OC}$ in reef water] $-[\mathrm{OC}$ in offshore water] $) \times D / T$

where $\mathrm{OC}$ is concentration of organic carbon $\left(\mu \mathrm{M}=\mathrm{mmol} \mathrm{m}^{-3}\right), D$ is average water depth $(\mathrm{m})$ and $T$ is residence time of reef water $(\mathrm{d})$.

In the estimation here, residence time was set at $6 \mathrm{~h}$ $(=0.25 \mathrm{~d})$ (see description in 'Materials and methods'). Using the equation, the fluxes of DOC and POC were estimated at 36 and $7 \mathrm{mmolC} \mathrm{m} \mathrm{m}^{-1}$, respectively. The values were comparable with that of the previous reports, although little information is available on DOC and POC flux in coral reefs and other coastal aquatic ecosystems. Ikeda et al. (1995) measured the concentrations of DOC and POC in seawater flowing across the reef flat of Palau (western Pacific) and estimated the daily flux as $64 \mathrm{mmol} \mathrm{C} \mathrm{m}^{-2} \mathrm{~d}^{-1}$. Ziegler \& Benner (1999) estimated the DOC flux in a subtropical seagrass-dominated lagoon (Laguna Madre, Texas) as 4 to $25 \mathrm{mmolC}$ $\mathrm{m}^{-2} \mathrm{~d}^{-1}$. As for POC flux, Johannes (1967) reported that the flux of particulate organic materials (POM) on the reef flat of Enewetok atoll (Marshall Islands) is $200 \mathrm{mg}$ $\mathrm{m}^{-2} \mathrm{~h}^{-1}$. If we assume that POM has a $40 \%$ carbon content and the POM flux rate is constant throughout the day, the data can be converted to $20 \mathrm{mmolC} \mathrm{m} \mathrm{m}^{-2} \mathrm{~d}^{-1}$.

\section{Production and consumption of organic carbon in reef water}

One of the main sources of organic carbon in seawater on the reef flat is attributable to a release of organic materials by coral (Marshall 1965, Coles \& Strathmann 1973). Symbiotic algae (zooxanthellae) in a host coral ex- crete 80 to $95 \%$ of the photosynthetically fixed carbon to the coral (Davies 1984, Muscatine et al. 1984, Edmond \& Davies 1986). The coral respire some part of the organic carbon and secrete the rest into the surrounding waters, which is about 6 to $48 \%$ of photosynthetically fixed carbon (Crossland et al. 1980, Davies, 1984, Muscatine et al. 1984, Edmond \& Davies 1986). Coral mucus consists of neutral sugars, amino sugars, proteins, phospholipids, triglycerides, sterols and wax esters (Benson \& Muscatine 1974, Ducklow \& Mitchell 1979, Crossland 1987), which can be used as a food source for bacteria which are considered as a main consumer of DOM and POM in seawater (Moriarty et al. 1985a, Ducklow 1990). Stimulation of bacterial growth by the coral mucus has been observed (Paul et al. 1986, Schiller \& Hendl 1989, Gast et al. 1998), but the quantitative importance of degradation of DOC and POC in carbon flux is difficult to assess as it depends on: (1) The mucus production rate; (2) The degradation rate in ambient conditions; and (3) The carbon conversion efficiency of bacteria on mucus (Torreton 1998). Bacterial production reported over coral reef waters show a wide range from 0.02 to $147 \mathrm{\mu g} \mathrm{C} \mathrm{l}^{-1} \mathrm{~d}^{-1}$ (Moriarty et al. 1985b, Liney \& Koop 1986, Sorokin 1994, Torreton et al. 1997, Ferrier-Pages \& Gattuso 1998). In Shiraho reef, the bacterial production in the water column was estimated to be 20 to $30 \mu \mathrm{g} \mathrm{Cl}^{-1} \mathrm{~d}^{-1}$ (A. Watanabe unpubl. data), but the data in the sediments is not available at present. Very few data have been reported for the bacterial production in the reef sediments; Those that have ranged from 20 to $370 \mathrm{mgC} \mathrm{m}^{-2} \mathrm{~d}^{-1}$ with around an average of $130 \mathrm{mg} \mathrm{C} \mathrm{m}^{-2} \mathrm{~d}^{-1}$ (Moriarty et al. 1985b, Moriarty \& Hansen 1990, Hansen et al. 1992). With the data available, we have primarily assumed the bacterial production rate in water and sediments on Shiraho reef as $25 \mu \mathrm{gC}(2 \mu \mathrm{mol}) \mathrm{l}^{-1} \mathrm{~d}^{-1}$ and $130 \mathrm{mgC}$ $(11 \mathrm{mmol}) \mathrm{m}^{-2} \mathrm{~d}^{-1}$, respectively. The areal bacterial production rate was estimated to be $15 \mathrm{mmol} \mathrm{C} \mathrm{m}^{-2} \mathrm{~d}^{-1}$, with an average water depth of $2 \mathrm{~m}$ in Shiraho reef. As for carbon conversion efficiency, a value of $50 \%$ (Ducklow 1983) has frequently been adopted in calculations of car- 
bon budgets in the previous studies (Moriarty et al. 1985b, Moriarty \& Hansen 1990, Hansen et al. 1992). However, lower values ( 7 to $20 \%$ ) have been observed in oligotrophic regions (Bjørnsen 1986, Hendl \& Velimirov 1986, Torreton 1999). When we adopted the conversion efficiency of 20 and $50 \%$, the bacterial consumption of $\mathrm{DOC}+$ POC were estimated as 75 and $30 \mathrm{mmolC} \mathrm{m}^{-2} \mathrm{~d}^{-1}$, respectively.

\section{Vertical flux of POC outside the reef}

Fig. 5 shows the time series of the vertical fluxes of POC and PON at a depth of $40 \mathrm{~m}$ at $1 \mathrm{~km}$ from the reef. Vertical fluxes of POC and PON (average \pm SE) were $1.03 \pm 0.07$ and $0.11 \pm 0.01 \mathrm{mmol} \mathrm{m}^{-2} \mathrm{~d}^{-1}$, respectively (Fig. 5, Table 3). A sediment trap is one method used to evaluate the flux of POM, but the data are quite limited outside the reef areas (Delesalle et al. 1998, Hata et al. 1998). The POC flux of this study was comparable with that in Palau reef under similar conditions (Hata et al. 1998), but the reported data for Tiahura reef (Moorea Island, French Polynesia) (Delesalle et al. 1998) was lower (0.20 mmolC m $\mathrm{m}^{-2} \mathrm{~d}^{-1}$ at $30 \mathrm{~m}$ depth and $10 \mathrm{~m}$ above the bottom) (Table 3 ). The sedimentation rates obtained in the coral reef lagoons show a wide range from 73 to 3900 mg (6 to 325 mmol) C m ${ }^{-2} \mathrm{~d}^{-1}$ (Koop \& Larkum 1987, Charphy \& Charpy-Roubaud 1991, Hansen et al. 1992, Clavier et al. 1995, Hata et al. 1998), but were higher than those outside the reef.

The daily sedimentation rate of POC outside the reef was compared to the daily areal POC flux on the reef. Because of the short residence time of seawater on the Shiraho reef (4 to $8 \mathrm{~h}$ ), we can assume that most of the POC in seawater which is released on the reef flat is subsequently exported to offshore. The vertical flux of POC outside the reef $\left(1.0 \mathrm{mmolC} \mathrm{m} \mathrm{m}^{-2} \mathrm{~d}^{-1}\right)$ was 14 to $20 \%$ of the POC flux on the reef (5 to $7 \mathrm{mmolC} \mathrm{m} \mathrm{m}^{-2} \mathrm{~d}^{-1}$ ), indicating that more than $80 \%$ of POC was decomposed during sedimentation outside the reef. The similar

Fig. 5. (A) Time series of the tide offshore. (B) Vertical fluxes of POC and PON at $40 \mathrm{~m}$ depth at $1 \mathrm{~km}$ off the reef. MSL: mean sea level

Table 3. Sedimentation rates outside the coral reef (mean $\pm \mathrm{SE}$ ). -: not reported

\begin{tabular}{|c|c|c|c|c|c|c|c|c|}
\hline Study site & $\begin{array}{l}\text { Study } \\
\text { period }\end{array}$ & $\begin{array}{c}\text { Distance } \\
\text { from reef } \\
\text { edge } \\
(\mathrm{km})\end{array}$ & $\begin{array}{l}\text { Sampling } \\
\text { maximum } \\
\text { depths } \\
\text { (m) }\end{array}$ & $\begin{array}{c}\text { POC in } \\
\text { surface } \\
\text { water } \\
(\mu \mathrm{M})\end{array}$ & $\begin{array}{l}\text { POC } \\
\text { flux }\end{array}$ & $\begin{array}{l}\text { PON } \\
\text { flux }\end{array}$ & $\begin{array}{l}\text { Molar } \\
\mathrm{C} / \mathrm{N} \\
\text { ratio }\end{array}$ & Source \\
\hline $\begin{array}{l}\text { Shiraho } \\
\text { (Ishigaki Island, Japan) }\end{array}$ & Sep 98 & 1 & $40(60)$ & 2.3 & $\begin{array}{c}1.03 \pm 0.07 \\
(\mathrm{n}=6)\end{array}$ & $0.11 \pm 0.01$ & 9.6 & This study \\
\hline $\begin{array}{l}\text { Palau } \\
\text { (Western Pacific) }\end{array}$ & Aug 95 & 2.5 & $\begin{array}{r}50(>700) \\
150(>700) \\
300(>700)\end{array}$ & 3.8 & $\begin{array}{l}1.08 \pm 0.28^{\mathrm{a}} \\
0.53 \pm 0.11^{\mathrm{a}} \\
0.40 \pm 0.02^{\mathrm{a}}\end{array}$ & $\begin{array}{l}0.15 \pm 0.03^{\mathrm{a}} \\
0.07 \pm 0.01^{\mathrm{a}} \\
0.03 \pm 0.00^{\mathrm{a}}\end{array}$ & $\begin{array}{r}7.2 \\
7.6 \\
13.3\end{array}$ & Hata et al. (1998) \\
\hline $\begin{array}{l}\text { Tiahura } \\
\text { (Moorea Island, } \\
\text { French Polynesia) }\end{array}$ & Sep 93 & - & $\begin{array}{l}\text { ca. } 38(40) \\
30(40) \\
420(430)\end{array}$ & $2.7^{\mathrm{c}}$ & $\begin{array}{l}4.69 \pm 0.50^{\mathrm{b}} \\
0.20 \pm 0.02^{\mathrm{b}} \\
0.37 \pm 0.06^{\mathrm{b}}\end{array}$ & & 9 & Delasalle et al. (1998) \\
\hline
\end{tabular}


result was reported by Hata et al. (1998), the sedimentation rate outside the coral reef in Palau at $50 \mathrm{~m}$ depth was $35 \%$ of export POC. We also examined the relationships between day-to-day variations of the sedimentation rates outside the reef and the variations of the $P_{\mathrm{n}}$, and the concentrations and fluxes of DOC and POC, but the relationship was not clear. Further information is needed to characterize the sedimentation pattern outside the reef, such as a long-term study including information on hydrodynamics.

\section{Composition of organic materials}

The $\mathrm{C} / \mathrm{N}$ ratios of organic particles may give some insight into their origins. The $\mathrm{C} / \mathrm{N}$ ratios of some potential sources of particulate materials have been reported: Phytoplankton (6 to 8: Parsons et al. 1961), benthic marine plant (20: Atkinson \& Smith 1983), coral mucus (6.9 to 13.7: Johannes 1967), mucous sheet of coral (4.8 to 5.9: Cofforth 1990) and terrestrial vascular plant (>30: Alexander 1977). According to the molar $\mathrm{C} / \mathrm{N}$ ratio of particulate materials obtained in this study $(5.5 \pm 0.3 ; \mathrm{n}=37)$, we suppose that the organic particles in the Shiraho reef mainly originate from mucus and mucous sheet of corals and that the effect of vascular plants is small. The concentrations of chlorophyll a $(\mathrm{chl} \mathrm{a})$ in the water was $0.15 \pm 0.01 \mu \mathrm{g} \mathrm{l} \mathrm{l}^{-1}$ $(\mathrm{n}=37$ ). Assuming that the $\mathrm{C} / \mathrm{chl} a$ ratio $=30$ (Banse 1977), the contributions of phytoplankton biomass to the POC was estimated to be $12 \%$.

The $\mathrm{C} / \mathrm{N}$ ratio of the trapped particles outside the reef was 9.6, which was greater than that of reef water (5.5) or POM in the surface water in offshore zone $(5.1 \pm 0.3 ; \mathrm{n}=10)$, suggesting the loss of nitrogen during the sedimentation. One other important aspect is the identification of the organic materials collected outside the reef in order to show the origin of the materials. It is important to evaluate the contribution of the reef organisms on the sinking particles collected outside the reef, but we have little information at present. The ratios of carbon to nitrogen or chl a (Hata et al. 1998) and the content of carbohydrates, amino acids and sugars (Delasalle et al. 1998) have been reported. However, the data for fatty acid compositions or stable isotope values are much more informative to identify the origin of the organic materials, which is a study required for the near future.

\section{Organic carbon budget in Shiraho reef}

The daily carbon budget in Shiraho reef during the study period was examined (Table 4) and the data obtained was assumed to be representative of the study area.

It was suggested that inshore corals derive much of their nutrients from terrestrial sources (Risk et al. 1994); However, no depletion in salinity by freshwater input and lower $\mathrm{C} / \mathrm{N}$ ratio of particulate materials (discussed above) indicated that the effect of terrestrial materials on POC and DOC fluxes was negligible during the study period.

Primary producers on the reef flat fixed carbon at the rate of $632 \mathrm{mmolC} \mathrm{m} \mathrm{m}^{-2} \mathrm{~d}^{-1}$. Although most of this fixed carbon was consumed by community respiration (596 mmolC m $\mathrm{m}^{-2} \mathrm{~d}^{-1}$ ), a large amount of the fixed carbon was left as $P_{\mathrm{n}}\left(36 \pm 12 \mathrm{mmolC} \mathrm{m}^{-2} \mathrm{~d}^{-1}\right)$. The apparent flux of DOC + POC was estimated to be 35 to $43 \mathrm{mmolC} \mathrm{m} \mathrm{d}^{-1}$, which was 6 to $7 \%$ of $P_{\mathrm{g}}$ and almost equivalent to $P_{\mathrm{n}}$ during the study period. The heterotrophic consumption of organic carbon by bacterial activity, 30 to $75 \mathrm{mmolC} \mathrm{m} \mathrm{m}^{-2}$, was assumed from the data available from the previous reports. With the numbers estimated, the release of POC + DOC from the primary producers were estimated to be 69 to $114 \mathrm{mmolC}$ $\mathrm{m}^{-2} \mathrm{~d}^{-1}$, which was 11 to $18 \%$ of the $P_{\mathrm{g}}$. The bacterial consumption of DOC + POC was assumed to be about 43 to $66 \%$ of DOC + POC production by the primary producers during the study period. Because of the short residence time of seawater on the Shiraho reef ( 4 to $8 \mathrm{~h}$ : H. Yamano unpubl. data), most of the organic materials remained in seawater on the reef flat and was subsequently exported to offshore. With $\mathrm{POC}$, the sediment trap study indicated that $1 \mathrm{mmolC} \mathrm{m} \mathrm{m}^{-2} \mathrm{~d}^{-1}$, which is equivalent to about 14 to $20 \%$ of the POC exported

Table 4. Daily carbon budget in Shiraho coral reef (21 to 24 September 1998)

\begin{tabular}{|c|c|c|c|}
\hline & Method & $\begin{array}{c}\text { Flux } \\
\left.\text { mmol C m }{ }^{-2} \mathrm{~d}^{-1}\right)\end{array}$ & $\begin{array}{c}\% \text { of } \\
P_{g}\end{array}$ \\
\hline Gross community production $\left(P_{\mathrm{g}}\right)$ & \multirow{4}{*}{$\begin{array}{l}\text { Measurement } \\
\text { of TA and TIC }\end{array}$} & 632 & 100 \\
\hline Daily community respiration $(R)$ & & 596 & 94 \\
\hline Daily net community production $\left(P_{\mathrm{n}}\right)$ & & $36 \pm 12$ & 6 \\
\hline Net community calcification $\left(G_{n}\right)$ & & 127 & - \\
\hline Apparent flux of DOC on the reef & HTCO method & $30-36$ & $5-6$ \\
\hline Apparent flux of POC on the reef & $\mathrm{CHN}$ analyzer & $5-7$ & 1 \\
\hline $\begin{array}{l}\text { Bacterial heterotrophic consumption } \\
\text { of DOC + POC on the reef }\end{array}$ & $\begin{array}{l}\text { Estimated from the } \\
\text { reported data }\end{array}$ & $30-75$ & $5-12$ \\
\hline $\begin{array}{l}\text { Excretion of DOC + POC } \\
\text { by primary producers }\end{array}$ & Calculated & $69-114$ & $11-18$ \\
\hline $\begin{array}{l}\text { Vertical flux of POC outside the reef } \\
\text { (1 km off reef and } 40 \mathrm{~m} \text { depth) }\end{array}$ & $\begin{array}{l}\text { Sediment trap } \\
+ \text { CHN analyzer }\end{array}$ & 1 & 0.2 \\
\hline
\end{tabular}


from the reef flat ( 5 to $7 \mathrm{mmolC} \mathrm{m}^{-2} \mathrm{~d}^{-1}$ ) and $0.2 \%$ of the $P_{\mathrm{g}}$, reached $1 \mathrm{~km}$ off the reef and $40 \mathrm{~m}$ depth. Although all the values have uncertainties, we showed that the flux of DOC and POC in Shiraho reef was in good accordance with the estimated community production during the study period.

Acknowledgements. We would like to thank Dr Miyajima and Mr Y. Umezawa at the Ocean Research Institute of the University of Tokyo, Mr O. Abe at the Institute for Hydrospheric Atmospheric Sciences, University of Nagoya, Mr A. Watanabe at the Univertisty of Tokyo, Mr K. Nozaki, Mr A. Negishi and M. K. Kato from the Electrotechnical Laboratory for water samplings during the study period. Mr F. Akimoto, Mr K. Kawate, Mr T. Kitoh and Mr E. Shimabukuro at Fuyo Ocean Development \& Engineering are acknowledged for support of the field survey. We are grateful to the Japan Sea-Farming Association, Yaeyama Station, for providing the laboratory. Mr Hamada at Nichiyu Giken Kogyo Co. Ltd. is acknowledged for technical support of a newly developed time-series sediment trap. We also thank Miss M. Nozawa and Mr E. Sasaki at the Marine Biotechnology Institute for assistance in DOC and POC analysis, and Miss A. Muramoto at the Japan Science and Technology Corporation for data processing. Prof I. Koike at the Ocean Research Institute of the University of Tokyo is acknowledged for valuable comments on the data analysis. We are also grateful to Dr Ikuro Sato at the Miyagi Cancer Center for a discussion of statistical analysis. This work was supported by the New Energy and Industrial Technology Development Organization (NEDO) and Core Research for Evolutional Science and Technology (CREST), program of Japan Science and Technology (JST) Corporation.

\section{LITERATURE CITED}

Alexander M (1977) Introduction to soil microbiology, 2nd edn. Wiley-Liss, New York

Atkinson MJ, Grigg RW (1984) Model of a coral reef ecosystem II. Gross and net benthic primary production at French Frigate Shoals, Hawaii. Coral Reefs 3:13-22

Atkinson MJ, Smith SV (1983) C:N:P ratios of benthic marine plants. Limnol Oceanogr 28:568-574

Banse K (1977) Determing the carbon-to-chlorophyll ratio of natural phytoplankton. Mar Biol 41:199-212

Barnes DJ, Lazar B (1994) Metabolic performance of a shallow reef patch near Eilat on the Red Sea. J Exp Mar Biol Ecol 174:1-13

Benson AA, Muscatine L (1974) Wax in coral mucus: energy transfer from corals to reef fishes. Limnol Oceanogr 19: 810-814

Bjørnsen PK (1986) Bacterioplankton growth yield in continuous seawater cultures. Mar Ecol Prog Ser 30:191-196

Chalker BE (1981) Simulating light-saturation curves for photosynthesis and calcification by reef-building corals. Mar Biol 63:135-141

Charpy LC, Charpy-Roubaud CJ (1991) Particulate organic matter fluxes in a Tuamotu atoll lagoon (French Polynesia). Mar Ecol Prog Ser 71:53-63

Clavier J, Chardy P, Chevillon C (1995) Sedimentation of particulate matter in the south-west lagoon of New Caledonia: spatial and temporal patterns. Estuar Coast Shelf Sci 40:281-294

Cofforth MA (1990) Mucus sheet formation on poritid corals: an evaluation of coral mucus as a nutrient source on reefs. Mar Biol 105:39-49

Coles SL, Strathman R (1973) Observations on coral mucus flocs and their potential trophic significance. Limnol Oceanogr 18:673-678

Crossland CJ (1987) In situ release of mucus and DOC-lipid from the corals Acropora variabilis and Styropora pistilata. Coral Reefs 6:35-42

Crossland CJ, Barnes DJ, Borowitzka MA (1980) Diurnal lipid and mucus production in the staghorn coral Acropora acuminata. Mar Biol 60:81-90

Davies PS (1984) The role of zooxanthellae in the nutritional energy requirements of Pocillopora eydouxi. Coral Reefs 2:181-186

Delesalle B, Buscail R, Carbonne J, Courp T and 4 others (1998) Direct measurements of carbon and carbonate export from a coral reef ecosystem (Moorea Island, French Polynesia). Coral Reefs 17:121-132

DOE (Department of Energy) (1994) Handbook of methods for the analysis of the various parameters of the carbon dioxide system in sea water. In: Dickson AG, Goyat C (eds) Version 2.1, ORNL/CDIAC-74, US Department of Energy, Washington, DC

Ducklow HW (1983) Production and fate of bacteria in the oceans. Bioscience 33:494-501

Ducklow HW (1990) The biomass, production and fate of bacteria in coral reefs. In: Dubinsky Z (ed) Coral reefs. Elsevier, Oxford, p 265-289

Ducklow HW, Mitchell R (1979) Composition of mucus released by coral reef coelenterates. Limnol Oceanogr 24: 706-714

Edmonds PJ, Davies PS (1986) An energy budget for Porites porites (Scleractinia). Mar Biol 92:339-347

Erez J (1990) On the importance of food sources in coral-reef ecosystems. In: Dubinsky Z (ed) Coral reefs. Elsevier, Oxford, p 411-418

Ferrier-Pagès C, Gattuso JP (1998) Biomass, production and grazing rates of pico- and nanoplankton in coral reef waters (Miyako Island, Japan). Microb Ecol 35:46-57

Ferrier-Pagès C, Gattuso JP, Cauwet G, Laubert J, Allemand D (1998) Release of dissolved organic carbon and nitrogen by the zooxanthellae coral Galaxea fascicularis. Mar Ecol Prog Ser 172:265-274

Gast GJ, Wiegman S, Wieringa E, van Duy FC, Bak RPM (1998) Bacteria in coral reef water types: removal of cells, stimulation of growth and mineralization. Mar Ecol Prog Ser 169:1-11

Gattuso JP, Pichon M, Delesalle D, Canon C, Frankignoulle M (1996) Carbon fluxes in coral reefs. I. Lagrangian measurement of community metabolism and resulting air-sea $\mathrm{CO}_{2}$ disequilibrium.

Hansen JA, Klumpp DW, Alongi DM, Dayton PK, Riddle MJ (1992) Detrital pathways in a coral reef lagoon II. Detritus deposition, benthic microbial biomass and production. Mar Biol 113:363-372

Hata H, Suzuki A, Maruyama T, Kurano N, Ikeda Y, Miyachi S, Kayanne H (1998) Carbon flux by suspended and sinking particles around the barrier reef of Palau, western Pacific. Limnol Oceanogr 43:1883-1893

Hendl GJ, Velimirov B (1986) Microheterotrophic utilization of mucus released by the Mediterranean coral Cladocora cepitosa. Mar Biol 90:363-369

Ikeda Y (1997) Carbon dynamics in the coral reef ecosystem. $\mathrm{PhD}$ thesis, University of Tokyo

Ikeda Y, Hata H, Suzuki A, Kayanne H (1995) Diurnal carbon flux at the barrier reef in Palau. Proc 8th Int Coral Reef Symp Panama 1:965-970 
Iryu Y, Nakamori T, Matsuda S, Abe O (1995) Distribution of marine organisms and its geological significance in the modern reef complex of the Ryukyu Islands. Sediment Geol 99:243-258

Johannes RE (1967) Ecology of organic aggregates in the vicinity of a coral reef. Limnol Oceanogr 12:189-195

Johannes RE, Project Symbios Team (1972) The mechanism of some coral reef communities: a team study of nutrient and energy flux at Enewetok. Bioscience 22:541-54

Kayanne H, Suzuki A, Saito H (1995) Diurnal changes in the partial pressure of carbon dioxide in coral reef water. Science 269:214-216

Kayanne H, Harii S, Yamano H, Tamura M, Ide Y, Akimoto F (1999a) Changes in living coral coverage before and after the 1998 bleaching event on coral reef flats of Ishigaki Island, Ryukyu Islands. Galaxea 1:73-82 (in Japanese with English abstract)

Kayanne H, Kudo S, Hata H, Nozaki K, and 5 others (1999b) Monitoring system for changes in coral reef water $p \mathrm{CO}_{2}$ and community metabolism. In: Nojiri Y (ed) $\mathrm{CO}_{2}$ in the Ocean. Proc 2nd Int Symp, $\mathrm{CO}_{2}$ in the Ocean. Tsukuba, Japan, p 407-411

Kayanne H, Kudo S, Hata H, Yamano H and 6 others (in press) Integrated monitoring system for coral reef water $p \mathrm{CO}_{2}$, carbonate system and physical parameters. Int Proc 9th Coral Reef Symp

Kimoto H, Nozaki K, Kudo S, Kato K, Negishi A, Kayanne H (2002) Achieving high time-resolution with a new flowthrough type analyzer for total inorganic carbon in seawater. Anal Sci 18:247-253

Kinsey DW (1975) Productivity and calcification estimates using slack-water periods and field enclosures. In: Stoddart DR, Johannes RE (eds) Coral reefs: research methods. UNESCO, Paris, p 439-468

Koop K, Larkum AWD(1987) Deposition of organic material in a coral reef lagoon, One Tree island, Great Barrier Reef. Estuar Coast Mar Sci 25:1-9

Lewis JB (1977) Process of organic production on coral reefs. Biol Rev 52:305-347

Liney EAS, Koop K (1986) Significance of pelagic bacteria as a trophic resource in a coral reef lagoon, One Tree Island, Great Barrier Reef. Mar Biol 92:457-464

Marshall N (1965) Detritus over the reef and its potential contribution to adjacent waters of Eniwetok Atoll. Ecology 46: 343-344

Millero FJ, Pisson A (1981) International one-atmosphere equation of state of seawater. Deep-Sea Res 28:625-629

Miyatake O, Wakimono K (1978) Random numbers and a Monte Carlo method. Morikita Press, Tokyo (in Japanese)

Moriarty DJW, Hansen JA (1990) Productivity and growth rates of coral reef bacteria on hard calcareous substrates and in sandy sediments in summer. Aust J Mar Freshw Res 41:785-794

Moriarty DJW, Pollard PC, Alongi DM, Wilkinson CR, Gray JS (1985a) Bacterial productivity and trophic relationships with consumers on a coral reef (MECOR I). Proc 5th Int Coral Reef Congr Tahiti 3:457-462

Moriarty DJW, Pollard PC, Hunt WG (1985b) Temporal and spatial variation in bacterial production in the water column over a coral reef. Mar Biol 85:285-292

Müller TJ (1999) Determination of salinity. In: Grasshoff K, Kremling K, Ehrhardt M (eds) Methods of seawater analysis. Wiley-Vch, Weinheim, p 41-73

Muscatine L, Porter JW (1977) Reef corals: mutualistic symbiosis adapted to nutrient poor environments. BioScience 27:454-460

Editorial responsibility: Otto Kinne (Editor),

Oldendorf/Luhe, Germany
Muscatine L, Falkowski PG, Porter JW, Dubinsky Z (1984) Fate of photosynthetic fixed carbon in light- and shadeadapted colonies of the symbiotic coral Stylopora pistillata. Proc R Soc Lond B 222:181-202

Nakamori T, Suzuki A, Iryu Y (1991) Water circulation and carbon flux on Shiraho coral reef of the Ryukyu Islands, Japan. Cont Shelf Res 12:951-970

Parsons TR, Stephens K, Strickland JDH (1961) On the chemical composition of eleven species of marine phytoplanktons. J Fish Res Board Can 18:1001-1016

Paul JH, DeFlaun MF, Jefferey WH (1986) Elevated levels of microbial activity in the coral surface microlayer. Mar Ecol Prog Ser 33:29-40

Pomeroy LR (1970) The strategy of mineral recycling. Annu Rev Ecol Syst 1:171-190

Quasim SZ, Sankaranarayanan VN (1970) Production of particulate organic matter by the reef on Kavaratti atoll (Laccadives). Limnol Oceanogr 15:574-578

Risk MJ, Sammarco PW, Schwarcz HP (1994) Cross-continental shelf trends in delta-C-13 in coral on the Great Barrier Reef. Mar Ecol Prog Ser 106:121-130

Sato I (1997) The least-square method: theory and practice. Sankaido, Tokyo (in Japanese)

Schiller C, Herndl GJ (1989) Evidence of enhanced microbial activity in the interstitial space of branched corals - Possible implications for coral metabolism. Coral Reefs 7: 179-184

Smith SV (1973) Carbon dioxide dynamics: A record of carbon production, respiration and calcification in the Enewetok reef flat community. Limnol Oceanogr 18:106-120

Smith SV, Key GS (1975) Carbon dioxide and metabolism in marine environments. Limnol Oceanogr 20:493-495

Sorokin YI (1993) Organic matter in reef waters. In: Sorokin YI (ed) Coral reef ecology. Springer-Verlag, Berlin, p 65-72

Sorokin YI (1994) Role of plankton in the turnover of organic matter on the Great Barrier Reef, Australia. Hydrobiologia 308:35-44

Suzuki A, Nakamori T, Kayanne H (1995) The mechanism of production enhancement in coral reef carbonate systems: model and empirical results. Sediment Geol 99:259-280

Taguchi S (1982) Sedimentation of newly produced particulate organic matter in a subtropical inlet, Kaneohe Bay, Hawaii. Estuar Coast Shelf Sci 14:533-544

Taylor JR (1982) An introduction to error analysis: the study of uncertainties in physical measurements. University Science Books, Sausalito, CA

Torreton JP (1998) Bacterioplankton mediated organic cycling in the water column of coral reef waters. In: Abstracts from Int Workshop on $\mathrm{CO}_{2}$ Cycling and Metabolism in Coral Reef, Kyoto: Session 2

Torreton JP (1999) Biomass, production and heterotrophic activity of bacterioplankton in the Great Astrolabe Reef lagoon (Fiji). Coral Reefs 18:43-53

Torreton JP, Pages J, Dufour P, Gawet G (1997) Bacterioplankton carbon growth yield and DOC turnover in some coral reef lagoons. Proc 8th Int Coral Reef Symp 1:947-952

UNESCO (1981) Background papers and supporting data on the Practical Salinity Scale. Tech Pap Mar Sci 37, UNESCO, Paris

Yamamuro M, Kayanne H (1995) Rapid direct determination of organic carbon and nitrogen in carbonate bearing sediments using Yanaco MT-5 CHN analyzer. Limnol Ocenogr 40:1001-1005

Ziegler S, Benner R (1999) Dissolved organic carbon cycling in a subtropical seagrass-dominated lagoon. Mar Biol Prog Ser 180:149-160

Submitted: April 30, 2001; Accepted: November 20, 2001

Proofs received from author(s): April 7, 2002 